\title{
Towards better science and modesty in the Cognitive Science of Religion and Contemplative Science?
}

Citation for published version (APA):

Smolka, M. (2019). Towards better science and modesty in the Cognitive Science of Religion and Contemplative Science? Verkündigung und Forschung, 64(2), 142-150. https://doi.org/10.14315/vf-2019640208

Document status and date:

Published: 01/09/2019

DOI:

10.14315/vf-2019-640208

Document Version:

Accepted author manuscript (Peer reviewed / editorial board version)

Document license:

CC BY-NC-ND

\section{Please check the document version of this publication:}

- A submitted manuscript is the version of the article upon submission and before peer-review. There can be important differences between the submitted version and the official published version of record.

People interested in the research are advised to contact the author for the final version of the publication, or visit the DOI to the publisher's website.

- The final author version and the galley proof are versions of the publication after peer review.

- The final published version features the final layout of the paper including the volume, issue and page numbers.

Link to publication

\footnotetext{
General rights rights.

- You may freely distribute the URL identifying the publication in the public portal. please follow below link for the End User Agreement:

www.umlib.nl/taverne-license

Take down policy

If you believe that this document breaches copyright please contact us at:

repository@maastrichtuniversity.nl

providing details and we will investigate your claim.
}

Copyright and moral rights for the publications made accessible in the public portal are retained by the authors and/or other copyright owners and it is a condition of accessing publications that users recognise and abide by the legal requirements associated with these

- Users may download and print one copy of any publication from the public portal for the purpose of private study or research.

- You may not further distribute the material or use it for any profit-making activity or commercial gain

If the publication is distributed under the terms of Article $25 \mathrm{fa}$ of the Dutch Copyright Act, indicated by the "Taverne" license above, 


\section{Towards better science and modesty in the Cognitive Science of Religion and Contemplative Science?}

Mareike Smolka

Daniel Goleman/Richard J. Davidson, Altered Traits. Science Reveals How Meditation Changes Your Mind, Brain, and Body, Avery New York NY 2017, 330 p. - Wendy Hasenkamp/Janna $R$. White (Eds.), The Monastery and the Microscope. Conversations with the Dalai Lama on Mind, Mindfulness and the Nature of Reality, Yale University Press New Haven CT 2017, xii + 385 p. - Luther H. Martin/Donald Wiebe (Eds.), Religion Explained? The Cognitive Science of Religion After Twenty-Five Years (Scientific Studies of Religion: Inquiry and Explanation), Bloomsbury London 2017, xi +260 p.

Further Literature

Anne Koch/Katharina Wilkens (eds.), The Bloomsbury Handbook of Cognitive and Cultural Aesthetics of Religion, Bloomsbury Academic London 2019, 376 p. - Sebastian Schüler, Religion, Kognition, Evolution. Eine religionswissenschaftliche Auseinandersetzung mit der Cognitive Science of Religion (Religionswissenschaft heute 9), Kohlhammer Stuttgart 2012, 286 p. - Nicholas T. Van Dam/Marieke K. van Vugt/David R. Vago/Laura Schmalzl/Clifford D. Saron/ Andrew Olendzki/Ted Meissner/Sara W. Lazar/Catherine E. Kerr/Jolie Gorchov/Kieran C.R. Fox/Brent A. Field/Wilonghby B. Britton/Julie A. Brefczynski-Lewis/David E. Meyer, Mind the Hype: A Critical Evaluation and Prescriptive Agenda for Research on Mindfulness and Meditation: Perspectives on Psychological Science 13 (2018) 36-61 - B. Allan Wallace, Contemplative Science. Where Buddhism and Neuroscience Converge (Columbia Series in Science and Religion), Columbia University Press New York NY 2007, 211 p.

\section{Parallel evolutions}

Studying religious phenomena and practices with methods from the cognitive sciences, in particular the neurosciences, has come into fashion in the last decades. This kind of research has been advanced by two young fields of research, the cognitive science of religion (CSR) and contemplative science (CS). CSR draws on theories and methods from the cognitive sciences to explain mental processes underlying recurrent patterns of religious thought and behavior. CS subsumes research on contemplative practices, predominantly Buddhist meditation, and is promoted by the Mind \& Life Institute. The Mind \& Life Institute is an American non-profit organization whose mission is to support multidisciplinary scientific investigation of the mind and the benefits of meditation.

Both fields originated in the United States and have slowly found their way into European universities and research institutions. Although both fields are niche businesses, meditation research has gained increasing popularity in the public sphere. As Asian religious and healing practices have entered Western health care and wellness markets, scientific research that underpins the benefits of these practices has received growing attention. Accordingly, researchers and scholars who work in the field of CS have started to publish in formats that cater towards a broader audience. CSR publications, in contrast, have so far remained 
confined to an academic readership, but within religious studies CSR has gained attention. Sub-fields in religious studies, such as aesthetics of religion that explores the role of the body, the senses, and cognition in religious experience, have started to draw on CSR theories and findings (e.g., Koch/Wilkens).

Increased attention has been joined by increased critical commentary. Some religious studies scholars have questioned the relevance, methodology, and epistemology of CSR (e.g., S. Schüler). Consequently, the discourse in CSR has shifted towards a more reflexive tone. Pleas for better science and more modest claims have pervaded CSR. A similar discursive shift has taken place in CS. Scientists and scholars warn that the media hype around meditation and its research has fueled exaggerated claims about potential benefits of meditation (e.g., N.T. Van Dam et al.). They call for more scientific rigor and careful science communication.

The parallel evolutions in CSR and CS come to the fore in three recent book publications in which prominent figures of the two fields discuss the past, state of the art research, and future directions. How do the authors present the historical evolution of their respective field and which future developments do they suggest? Answering these descriptive questions introduces readers to CSR and CS from a history of science perspective. This provides a basis for evaluating suggestions for future developments. Are they feasible or empty rhetoric intended to appease critical voices?

\section{Cognitive Science of Religion}

The volume »Religion Explained? The Cognitive Science of Religion After Twenty-Five Years", edited by L.H. Martin/D. Wiebe, inverts the title of the seminal book »Religion Explained « published in 2001 by P. Boyer, one of CSR's founding fathers. This inversion interrogates to what extent religion has actually been »explained « by CSR. The editors, central figures within the North American Association for the Study of Religion, have purported from CSR's beginnings that it is one of the best approaches for a "scientific « study of religion. However, CSR's portrayal of science as physical and experimental has reheated old debates between supposedly opposing epistemological camps drawing on W. Dilthey's famous distinction between »explanation « and »understanding «; that is, between scientific empiricism and the more imaginative work of the arts and humanities. To respond to these debates, the editors invited key players in CSR to discuss the past, present, and future of the field.

Deciding upon a starting point of CSR has challenged the volume's authors. According to cognitive anthropologist S. Hrotic,

»[d]epending on how one defines our field (and I must admit there is little consensus - which may be indicative of the problem), identifying the proper landmark as the beginning of our field is problematic « (Martin/Wiebe, 181-192, 182).

Hrotic tries to avoid attaching the label CSR to the field he describes, because he considers it as »nomadic " (187), continually moving between departments 
of biology, linguistics, sociology, philosophy, psychology, neuroscience, anthropology, and religious studies. All these disciplines were affected by the »cognitive revolution « during the 1950 s and especially by the work of N. Chomsky on language. Religious studies scholars $U$. Schjødt and A.W. Geertz, who have been involved in experimental research on religious phenomena, elucidate that Chomsky aimed to specify the biologically hardwired principles of the mind that constrain all languages. This approach inspired religious studies scholars to challenge the »mind-blindness « of their discipline and to identify the cognitive constraints of symbolic-cultural systems (Martin/Wiebe, 57-67, 58). This was one of the objectives of Th. Lawson's and R.N. McCauley's »Rethinking Religion « published in 1990, which religious studies scholars generally perceive as the founding year of CSR (1). Yet, psychologists and neuroscientists may push the clock forward, since psychologist J. Barrett introduced the term »cognitive science of religion « only ten years later.

Rather than regarding the millennium as CSR's time of emergence, it may also be considered as the time when a major shift occurred in CSR - from »CSR 1.0 « to »CSR 2.0«, such as the historian of religion L. Ambasciano suggests (Martin/ Wiebe, 107-122, 108, 110). In the first wave of CSR, humanities scholars laid theoretical foundations. The second wave was introduced by an »experimental turn « (109). Since hypothesis-driven research involving the testing of predictions emerged as a method to study religions »scientifically«, critical voices have become louder. What anthropologist $H$. Whitehouse recalls as a "cognitive conspiracy bent on reforming the study of religion and setting it on a truly scientific footing " (Martin/Wiebe, 43-55, 47) in the 1990s has transformed into a full-blown controversy between CSR researchers and religious studies scholars for the last ten years. Schjødt and Geertz admit: »we cannot help but feeling that much of the hostility is somehow our own fault «(62). The hostility may partly be a reaction to CSR researchers' arrogant bearing at religious studies conferences in addition to an exclusionary rhetoric promoting CSR as the only meaningful study of religions. To appease hostility, the contributors to »Religion Explained? « use the volume as a platform to reach out to religious studies scholars. They try to better explain CSR's assumptions and methods, but also acknowledge that a lot of criticism they have faced is reasonable.

According to Schjødt and Geertz, experimentation is a common target for critics (62). They summarize religious studies scholars' critique of CSR as follows: CSR researchers do not account for the complexity of religious beliefs and traditions; they misconceptualize religious phenomena when conducting experiments with uninterested participants, usually Western university students, who are exposed to so-called »religious stimuli«, such as listening to the words »God « or »prophet«, in a laboratory setting; the results are overemphasized, difficult to replicate, and feed into overly bold interpretations that are not applicable to real-life situations. Schjødt and Geertz acknowledge that these statements are adequate for some CSR research. However, they point at three research trajec- 
tories that are already under way and that accommodate the aforementioned criticisms.

First, CSR researchers seem to be eager to collaborate with historians of religion. R.N. McCauley stresses the indispensability of historians joining the experimental ranks:

»Whether through providing speculative interpretive proposals, or counterinstances that challenge cognitive hypotheses, or recommendations for refining such hypotheses, [...] the history of religions can engage in myriad collaborative enterprises with cognitive scientists of religion « (Martin/Wiebe, 17-41, 19).

Similarly, anthropologists are recruited for »collaborative enterprises « so as to help CSR researchers develop research designs for the study of religious behavior in a contextually rich embedding. Collaborations with anthropologists facilitate two approaches that render experimental results more applicable to real-life settings: »authentic religion studies « (64) and experiments »in the natural « (39). Schjødt and Geertz introduce »authentic religion studies « as the examination of actual religious experiences and practices in the laboratory. To recruit religious practitioners and establish a context in which they have authentic experiences, anthropological expertise is needed. Similarly, when studying religious practices »in the natural «, such as McCauley proposes, anthropologists could help linking field observations with physiological measurements (39).

Contributors to the present volume agree that collaboration across different fields is indispensable for CSR to move forward towards a »holistic science of religion ", as anthropologist $R$. Sosis calls it (Martin/Wiebe, 155-167, 167). Sosis supposes that integrating perspectives and methods from within the humanities and across the humanities-science divide might bring about a third wave of CSR.

\section{Contemplative Science}

What may give rise to a third wave of CSR has always been at the heart of CS. The multidisciplinary study of contemplative practices is the mission of the Mind $\&$ Life Institute, which provides an institutional home for CS. The foundation of the organization in 1987 may be considered as the founding year of CS, even though the label was introduced more than twenty years later by religious studies scholar and Buddhist monk A. Wallace (Wallace). The institute has been a driving force for collaborations between researchers in biological, cognitive, and social sciences, as well as monastic scholars, practitioners, and intellectuals from the humanities. It provides a platform for exchange during its hitherto thirty-two Mind \& Life Dialogues between CS researchers and monastics, most prominently the Dalai Lama. The $26^{\text {th }}$ dialogue from 2013 is documented in the latest Mind \& Life publication »The Monastery and the Microscope«, edited by neuroscientist W. Hasenkamp together with writer J.R. White. Renowned CS figures present current developments and propose future trajectories. The 
publication is reviewed after introducing readers to the history of CS narrated in the popular science book»Altered Traits «. The review of the book highlights how the authors and former Mind \& Life board members, science journalist and psychologist $D$. Goleman and neuroscientists $R$. Davidson, interweave their biographies with the evolution of CS.

\section{a) "Altered Traits"}

Goleman and Davidson start their narrative in the 1970s when both had travelled to India, spending months with yogis and taking part in silent retreats to practice Buddhist meditation. After returning to Harvard University, both were convinced that they wanted to focus on meditation in their dissertations. Academic mentors warned them that this would be a »career-ending move « (6). Any research on consciousness was associated with the counterculture of psychedelic drugs at the time. Nevertheless, Goleman and Davidson both pursued their interest in meditation and started some writing and research together. They shared the idea that meditation could generate what they called »altered traits «: transformations of the self that would last (45). They assumed that meditation could give rise to qualities, such as compassion and kindness, that they had encountered among yogis and Buddhist monastics.

Goleman and Davidson describe how they have followed their hunch for altered traits throughout their careers. Their narrative builds up to the chapter »Hidden Treasure in which the authors recount how Davidson and his colleague A. Lutz, a French neuroscientist with meanwhile international reputation for his contributions to CS, stumbled upon »the holy grail: a neural signature showing an enduring transformation « (232). This signature decorates the book's cover page - an electroencephalogram of gamma brain waves that increase in amplitude. Davidson and Lutz noticed that gamma brain activity, the fastest of all brain wave types, was not only more elevated when yogis with lifelong meditation experience were asked to meditate. In comparison to people without meditation experience, yogis had twenty-five times greater amplitude gamma oscillations while resting. The researchers »were seeing for the first time a neural echo of the enduring transformations that years of meditation practice etch on the brain« (235).

Goleman and Davidson call this finding a »hidden treasure « because they seem to regard it as a jewel among the plethora of scientific research on meditation that has grown exponentially since the 1970s. The authors attribute the boost in research to the introduction of mindfulness-based stress reduction, in short MBSR, in the 1980s. MBSR is a secular, eight-week meditation program whose standard format lends itself as a study intervention. Study results in support of MBSR's positive effects on health and well-being have facilitated the program's introduction to psychotherapy, education, and business. Yet, Goleman and Davidson warn that these studies do not live up to their promises. Most of them are 
not reproducible because they suffer from weaknesses, such as the difficulty to measure the hours of meditation experience to assign study participants to »beginner « or »advanced « groups, missing definitions of the exact mental techniques that constitute a specific meditation practice, and the neglect to control for other factors that could generate the effects ascribed to meditation.

The authors end their narrative by calling upon meditation researchers to apply the strictest experimental standards and exercise modesty when communicating about their results. They attribute the hype around meditation both inside and outside of the academy to research on its practical benefits and juxtapose this kind of research with studies on the long-term effects in lifelong meditators. Yet, one may argue that images of yogis and monks with electrodes sticking to their skulls have equally gone viral. The mysticism around their inner qualities and skills may be one reason for the popularity of CS and a selling point of »Altered Traits«. Stories of yogis, monks, and gurus create red threads throughout the book. These stories tie together in the »Hidden Treasure « chapter, which helps the authors conclude that evidence for altered traits has finally become compelling.

\section{b) "The Monastery and the Microscope"}

Some of the study participants that feature prominently in Goleman and Davidson's narrative are invited to converse with CS researchers during the Mind \& Life Dialogues. The objectives of these exchanges are the generation of research ideas, the delineation of theoretical concepts, and the definition of research designs. In this way, the core program of the Mind \& Life Institute is supposed to be advanced: the integration of the first-person and the third-person perspective. Whereas science relies on third-person observation, F. Varela, one of the founding fathers of the Mind \& Life Institute, was convinced that first-person, interospective experience of contemplative practices should be used as equal instrument of investigation.

Even though this program is mentioned more than ten times in the documentation of the Mind \& Life Dialogue from 2013, only one of its contributors provides an example from her own research. T. Singer introduces her research as follows:

»I also want to tell you a story about how studying monks, in collaboration with my favorite study participant, Matthieu Ricard, helps us understand our models better. I will show you how we combine the first-person perspective and experience with scientific methods to develop a new way of thinking through this cooperation« (Hasenkamp/White, 234-269, 234-235).

Singer's research focuses on Buddhist compassion meditation, whose practitioners intend to cultivate the wish that people are relieved from suffering. Compassion is supposedly related to empathy, that is feeling what another person feels. When seeing how another person feels pain, parts of the brain that are known for processing pain are reactivated in the person who merely watches. 
However, when Singer observed Ricard's brain signals while he was engaging in compassion meditation, she was surprised. Ricard activated brain networks usually associated with positive feelings. Singer recounts:

"When he came out of the scanner I asked him, , What were you doing? Were you not suffering, not feeling the pain? [...] Matthieu explained from his first-person perspective what he was feeling. He said he felt very strong warmth and concern and a strong motivation to alleviate the suffering of the other, but not necessarily pain« (239-240).

Singer explains that this finding inspired her to differentiate between empathy and compassion. Whereas empathy increases negative feelings and emotional distress, compassion may be considered as a strategy to build resilience in the face of suffering and may motivate to take action that eases the pains of others.

Whether this model of compassion results from »collaboration « (234) - working together towards a shared goal - or »cooperation « (235) - division of labor - remains ambiguous, for Singer uses both terms in reference to her research with Ricard. Collaboration might be facilitated by Ricard's interest and background in science; he finished a doctoral degree in cell genetics before dedicating his life to Buddhist meditation. Thus, to educate »future scientific collaborators «(372), the CS community has started to invest in education programs that expose monastics to Western science courses in, among others, the neurosciences, biology, and physics. Turning monastics into scientists appears to be a path towards the integration of first- and third-person perspectives.

\section{Evaluation}

Recent publications on the evolutions of CSR and CS written by their leading scholars and researchers portray the fields' histories as arch-shaped tales. Research initiatives that were initially dismissed by other academics as a "career-ending move « or a »cognitive conspiracy « have matured over time and created stir. CSR induced a harsh controversy in religious studies about how to study religious phenomena »scientifically « while CS generated an exponential growth of publications and media interest. Both fields seem to have overcome the peak of the arch and their leading figures make efforts to direct the ride downwards by calling for better science and modesty.

Collaboration with other experts is depicted as the key to better science. These other experts - historians or anthropologists of religion in CSR and Buddhist monastics in CS - are supposed to open up new research topics, delineate concepts, and help to integrate subjective experience with physiological measurements. From a science studies perspective, the plea for collaboration is relevant but suggestive of naivety. A large body of literature has been generated in science studies that discusses the pitfalls of collaborations across expertise divides, such as difficulties in communication, asymmetric power relations, and incommensurable objectives. Will experts with different backgrounds take time to estab- 
lish a common vocabulary despite pressures to deliver quick results in today's academic climate? Who has the final say behind closed doors in the Mind \& Life Institute about which research to promote? Will historians and anthropologists of religion be able to advance their own objectives when collaborating with CSR researchers?

The issue of incommensurable objectives points at a post-structuralist critique of mixed methods approaches. When mixing quantitative and qualitative methods in a study, one tries to combine different research paradigms. Ideographic approaches in religious studies oppose nomothetic interests in CSR. Sosis' vision of a »holistic science of religion « might, thus, be a rhetorical move to pull religious studies scholars into CSR as mere research assistants who offer access to religious practitioners or observations to be made sense of.

A similar critique applies to CS with regards to the feasibility of integrating first- and third-person perspectives. The term »integration « seems to imply that CS tries to solve what the modern philosopher D. Chalmers refers to as the »hard problem « - the question how physical processes give rise to subjective experience. Whereas the »hard problem « has been a conundrum for centuries and will probably remain one for the time to come, paying attention to first-person accounts may improve meditation studies. Asking study participants to describe their meditation experience may allow researchers to check whether participants were following study instructions to direct their meditation or whether any other practice was involved.

Yet, cooperating with study participants who contribute self-reports does not require »future scientific collaborators « to be trained in monasteries. It is questionable whether introducing monastics to research teams necessarily leads to better science. Instead of including meditation practitioners who are convinced of meditation's positive effects, CS might benefit from adding researchers to their ranks who have no meditation experience. These researchers might interpret neuroscience data from meditation studies with a more skeptical mind and be more attentive to false positives.

With regards to pleas for modesty, »Religion Explained? «lives up to what the authors call for. They present their methods and approaches in a nuanced manner highlighting limitations and assumptions to respond to criticism raised by the religious studies scholarly community. Yet, the book may fail to reach this audience. Religious studies scholars may not make the effort to read the book since most volume contributions are densely written and presuppose familiarity with CSR literature.

The reviewed CS publications, in contrast, are written in a language that is comprehensible for a broader audience. Goleman does not write "Altered Traits « as a psychologist, but as a science journalist. He draws readers into his American Dream narrative about two imaginative scientists who were persistently swimming against the stream to realize their unorthodox research ideas and ultimately made ground-breaking discoveries. This storyline of success, however, does not 
match the appeal to meditation researchers to display modesty in science communication. The »Hidden Treasure« chapter on heightened gamma oscillations in yogis might make readers believe that Davidson and Lutz found the index for kindness. Yet, the interpretation of gamma waves is still widely debated among neuroscientists. Building the narrative up to this chapter and placing an image of gamma waves with increasing amplitude on the book cover mocks any call for modest science communication.

To sum up, shifting towards modesty and better science in CSR and CS not only in discourse but also in practice depends partly on central figures setting a good example. Collaboration across expertise divides may be one feasible path towards better science, but is not a universal remedy. It is time-consuming and often frustrating because it comes with challenges that should not be underestimated. Yet, pleas for collaboration seem to be indispensable when researchers equipped with quantitative methods start to colonize subject areas that have been studied by experts with qualitative or interospective methods for centuries. 